doi: 10.32620/oikit.2020.90.09

УДК 004.93

Хорошун Г. М.

\title{
МЕТОД КЛАСИФІКАЦЇ̈ ЗАДАЧ ОПТИКИ ТА ЛАЗЕРНОЇ ФІЗИКИ
}

\author{
Східноукраїнський національний університет імені Володимира Даля, \\ м. Сєвєродонецьк, Україна
}

\begin{abstract}
За останні десятиріччя завдяки використанню комп'ютерних технологій результати досліджень за певним напрямком науки та техніки накопичуються дуже швидко. В процесі створення бази даних та бази знань оптичних зображень виникла проблема відсутності класифікації розв'язаних задач, що ускладнює створення структури сховища даних. Класифікація як самих задач, так і отриманих результатів вимагає значної уваги 3 метою забезпечення їх швидкого та влучного пошуку та подальшого використання. Класифікація $€$ однією з найважливіших задач аналізу великих баз даних, що використовується в Data Mining. Оцінка точності класифікації може проводитися за допомогою крос-перевірки або тестової множини. Якщо точність класифікації тестової множини, відповідає встановленим вимогам, то запропонований метод є придатним до використання. В області оптики та лазерної фрізики розв'язувались задачі, які можна згрупувати за видом початкового поля: квазіплоска хвиля, Гаусов пучок, Лагер-Гаусов пучок; за типом транспаранта: амплітудного (гратка з біфуркацією штриха, екран 3 прямолінійним краєм або отвір певної геометричної форми) та фразового (подвійний клин, сходинка, спіраль); за характеристиками отриманого просторового розподілу світла - кількістю максимумів, мінімумів, нулів інтенсивності та інших значущих об'єктів. Але в той час питання щодо класифікації самих задач розглянуто вперше. В роботі розроблено метод класифікації задач з оптики та лазерної фрізики, який застосований до даних отриманих в результаті розв'язку задач дифракції, інтерференції та спостереження за мікрооб'єктами. Для проведення класифікації за допомогою математичних методів визначено формальний опис об'єктів, яким можна оперувати, і проводити класифікацію. Визначено класи для задач з оптики та лазерної фрізики завдяки аналізу сучасних оптичних досліджень. Обрано 5 класів: «зміст завдання», «спосіб розв'язку», «призначення», «ступінь складності», «спосіб вираження». Ознаки для класифікації задачі: «візуально-оптична», «оптична», «обчислювальна», «експериментальна», «якісна», «фрундаментальна», «прикладна», «проста», «складна», «текстова», «числова», «граффічна». Наведена схема класифікації задач з оптики та лазерної фрізики з використанням отриманих в них оптичних зображень. Прийняття рішення щодо визначення атрибутів проблеми здійснюється за допомогою методу дерев рішень. Обговорено застосування результатів у пошукових системах великих баз даних та проблеми розпізнавання образів.
\end{abstract}

Ключові слова: класифікація задач; дерево рішень; оптичне зображення.

\section{Постановка та аналіз проблеми}

За останні десятиріччя завдяки використанню комп'ютерних технологій результати досліджень за певним напрямком роботи накопичуються дуже швидко. В процесі створення бази даних та бази знань оптичних зображень виникла проблема відсутності класифікації розв'язаних задач, що ускладнює створення структури сховища даних. Класифікація як самих задач, так і отриманих результатів вимагає значної уваги з метою забезпечення їх швидкого та влучного пошуку та подальшого використання [1]. Класифікація є однією 3 найважливіших задач аналізу великих баз даних [2,3]. Оцінка точності класифрікації може проводитися за допомогою крос-перевірки або тестової множини [4,5]. Якщо точність класифікації тестової множини, відповідає 
встановленим вимогам, то запропонований метод $€$ придатним до використання. Класифікація оптичних задач пов'язана 3 аналізом та розпізнаванням оптичних зображень в системах машинного зору [6,7].

В області оптики та лазерної фрізики розв'язувались задачі, які можна згрупувати за видом початкового поля: квазіплоска хвиля, Гаусов пучок, ЛагерГаусов пучок; за типом транспаранта: амплітудного та фазового; за характеристиками отриманого просторового розподілу світла [8] - кількістю максимумів, мінімумів, нулів інтенсивності та інших значущих об'єктів. Але в той час питання щодо класифікації самих задач не розглядалось.

Отже, існує потреба класифрікації задач з оптики та лазерної фрізики з використанням у якості навчальної вибірки розв'язаних задач з дифракції, інтерференції, а також спостереження за мікро об'єктами. Класифікацію задач можна провести за допомогою визначення сутності властивостей наборів даних та дерев рішень [9].

\section{Математичний опис завдання}

Для проведення класифікації за допомогою математичних методів необхідно визначити фрормальний опис об'єкта, яким можна оперувати, і проводити класифікацію.

Для розв'язку проблеми класифікації задач необхідно виділити сутності властивостей наборів даних за якими ці об'єкти будуть розподілені на підставі їх подібності.

Якщо А - множина описів об'єктів, В - множина назв класів. Існує невідома цільова залежність відображення $\mathrm{f}: \mathrm{A} \rightarrow \mathrm{B}$, значення якої відомі лише на елементах скінченної навчальної вибірки $A^{m}=\left\{\left(a_{1}, b_{1}\right), \ldots,\left(a_{m}, b_{m}\right)\right\}$. Потрібно побудувати алгоритм $\mathrm{f}: \mathrm{A} \rightarrow \mathrm{B}$, здатний класифікувати довільний об'єкт $\mathrm{a} \in \mathrm{A}$.

\section{Класифікація оптичних задач}

Проведення оптичних досліджень спирається на використання декількох методів неруйнівного контролю: візуального, вимірювального, візуальнооптичного та оптичного. Візуальний контроль здійснюється органами зору, характеризується такими параметри ока людини, як роздільна здатність зору та ступінь розрізнення дефектів. Візуально-вимірювальний контроль забезпечує визначення розмірів об'єктів та форми, виявлення їх змін з використанням простих засобів: рулетка і мікрометр. Такий метод використовується при проведенні всіх оптичних досліджень, але він $\epsilon$ другорядним і в сутностях класифікації не використовується. Візуальний контроль із застосуванням таких оптичних приладів, як лупи, мікроскопа, зорової труби, телескопа, ендоскопа називається візуально-оптичним. 3 використанням цього методу проводились дослідження з визначення дисперсії мікрочастинок, їх руху в лазерному полі та підрахунку їх кількості [10]. Застосування оптичних методів для вивчення особливостей дифрагованого поля у вигляді часово-просторових розподілів інтенсивності та фрази наведено в роботах [11-13].

3 метою визначення класів для задач 3 оптики та лазерної фрізики здійснено розвиток роботи присвяченої класифікації задач з фрізики [14] та ії адаптацію під сучасні оптичні дослідження. До множини В віднесемо 5 ознак класифрікації об'єктів: «зміст завдання», «спосіб розв'язку», «призначення», «ступінь складності», «спосіб вираження». Множина А містить всі види задач які можна класифікувати за наведеними ознаками, а саме «візуально-оптична», 
«оптична», «обчислювальна»,

«експериментальна»,

«якісна», «фундаментальна», «прикладна», «проста», «складна», «текстова», «числова», «графрічна». Схема класифікації таких задач наведена на рисунку 1.

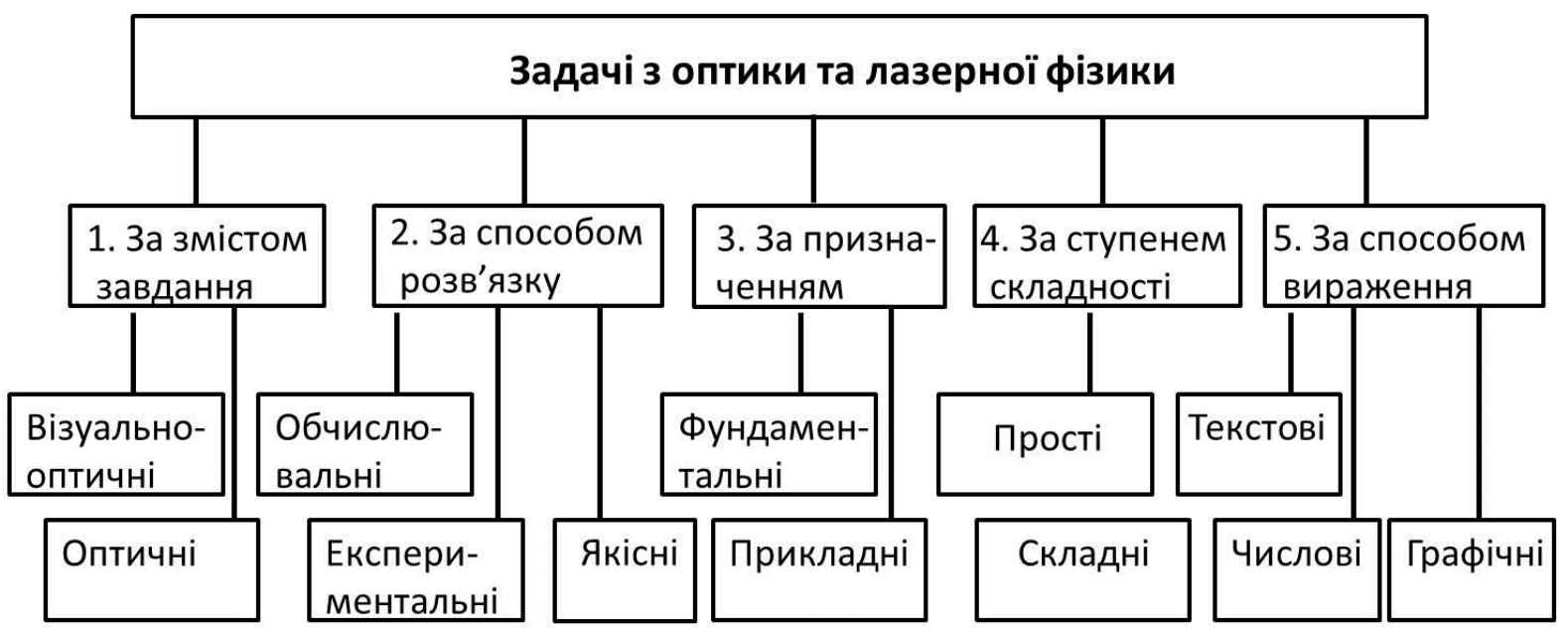

Рис.1 Класифрікація задач з оптики та лазерної фрізики

Розроблені дерева рішень, що дозволяють класифікувати задачу за обраними описами. Правила класифікації задач, які служать комплексним керівництвом для віднесення її до певного угруповання мають вигляд запитань та наведені на рис.2. Задача, яка містить об'єкт спостереження відноситься до візуально-оптичної, а така, в якій досліджуються характеристики світлового поля до оптичних. За способом розв'язку задачу можна віднести до якісної, обчислювальної чи експериментальної. Багато задач з часом проходять весь шлях їх розв'язку від якісної до обчислювальної та експериментальної. Фундаментальна проблема дозволяє збільшити кількість та якість знань, поліпшити розуміння оптичних явищ та процесів, а прикладна - розв'язати певну прикладну задачу з визначеними умовами. За ступенем складності задачі розділяються на прості - такі, в яких співпадають результати теорії та експерименту, та складні - такі, що відрізняються. Текстовий, числовий та графрічний способи вираження інформації $€$ основними, що використовуються.

Розподіл задач по характеру: «прості», «складні» проведений з огляду на те, що певні експериментальні результати для дифракції початкових полів у вигляді мод Лагера-Гауса з азимутальним індексом 2 та більше не збігаються 3 обчисленими результатами [13]. Причинами такого неспівпадіння можуть бути наступні: наближення теорії, обчислення похибки, не враховані шуми та аберації оптичних систем. Таким чином дифракційні задачі з початковими полями у вигляді квазі-плоскої хвилі, Гаусового пучка та Лагер-Гаусового 3 одиничний азимутальним індексом є простими.

За способом вираження розв'язаної задачі відповідь може бути текстова, наприклад за наявністю ефекту: «так», «ні» або для визначення рівня: «низький», «середній», «високий». Зазначимо, що кожна окрема задача може бути віднесена лише до одного з видів. Якщо за способом розв'язку наявні всі три типа, то це означає, що вона складається з трьох задач. 


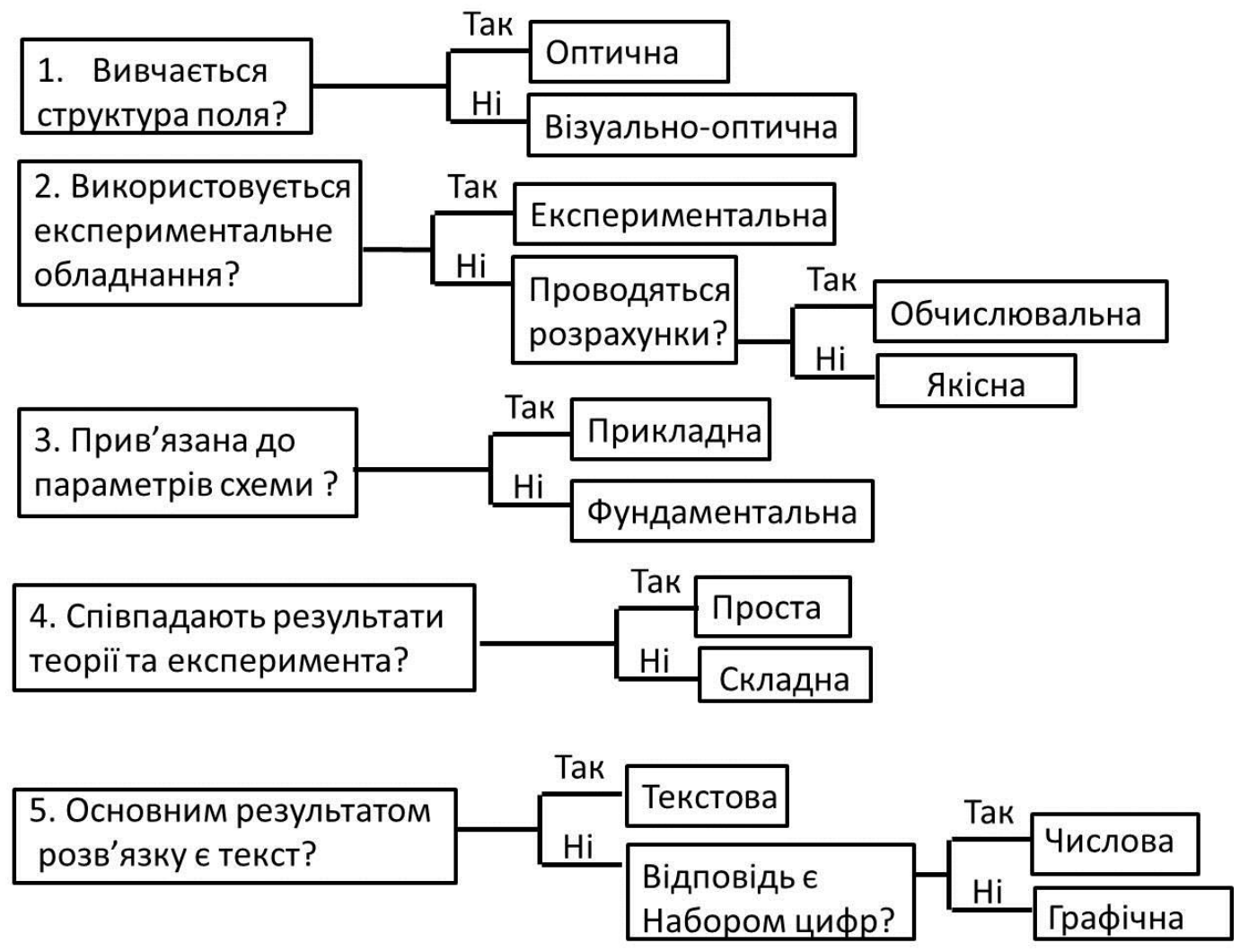

Рис. 2. Дерева рішень для визначення типу задачі

У якості прикладу застосування розвинутого метода класифікації задач розглянемо зображення на рис. 3. На зображені (рис.За) наведений фрагмент на якому відбувається спостереження за рухом мікрочастинок, що опромінюються лазерною хвилею [10]. Його отримано для візуально-оптичної, експериментальної, прикладної, простої, графрічної задачі. Зображення на рис. Зб отримано при дослідженні структури оптичного поля, що утворюється внаслідок дифракції Гаусова пучка на подвійному клині [11]. Така задача $є$

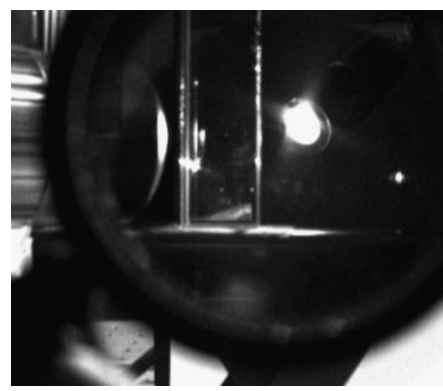

a

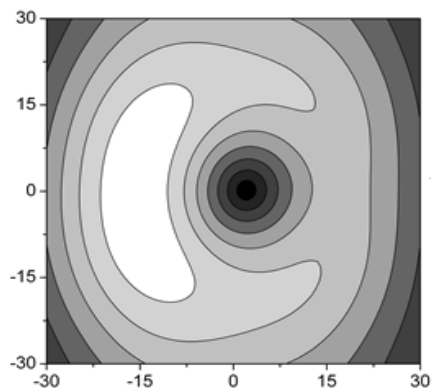

6

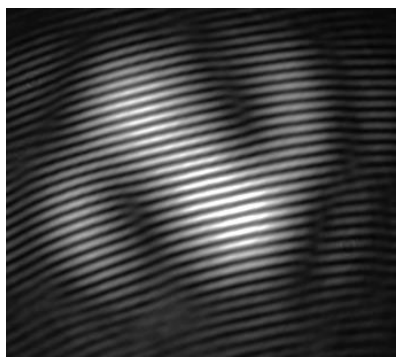

B

Рис. 3. Оптичні зображення для задач візуально-оптичного (а) та оптичного контроля (б,в). (а) Експериментальне зображення реєстрацію руху мікрочастинки за допомогою оптичної системи. (б) Розрахунковий розподіл інтенсивності при проходжені Гаусова пучка крізь подвійний фразовий клин. (в) Інтерфрерограма сфрормована при проходженні Лагер-Гаусова пучка крізь фразову сходинку. 
оптичною, обчислювальною, фундаментальною, простою, графрічною. Ще один розповсюджений тип зображень - це інтерференційна картина, вид якої отриманий при проходженні Лагер-Гаусова пучка крізь фазову сходинку [12] наведено на рис. Зв. За розробленою класифікацією її треба віднести до оптичної, експериментальної, фрундаментальної, простої графічної задачі. Наведені на рис. 3 зображення можна перевести в матриці чисел для подальшого аналізу.

Тестування наведеної класифікації 3 використанням дерев рішень проведено на 100 задач з оптики та лазерної фрізики та підтверджує високу точність розробленого методу класифікації.

\section{Висновки}

В роботі розроблено метод класифікації задач з оптики та лазерної фрізики, який застосований до даних отриманих в результаті розв'язку задач дифракції, інтерференції та спостереження за мікрооб'єктами. Для проведення класифікації за допомогою математичних методів визначено формальний опис об'єктів, яким можна оперувати, і проводити класифікацію.

Визначено класи для задач з оптики та лазерної фрізики завдяки аналізу сучасних оптичних досліджень. Обрано 5 класів: «зміст завдання», «спосіб розв'язку», «призначення», «ступінь складності», «спосіб вираження». Ознаки для класифікації задачі: «візуально-оптична», «оптична», «обчислювальна», «експериментальна», «якісна», «фундаментальна», «прикладна», «проста», «складна», «текстова», «числова», «графічна». Наведена схема класифікації задач з оптики та лазерної фізики.

Застосування отриманих результатів та рекомендацій можливе для пошуку корисної інформації в великих базах даних, задачах розпізнавання образів та для оцінки вартості виконання завдань з оптики та лазерної фрізики.

\section{Список літератури}

1. Квєтний, Р. Н., and О. А. Ремінний. "Високошвидкісний метод класифрікації зображень." (2009).

2. Lu, D. , \& Weng, Q. A. (2007). Survey of image classification methods and techniques for improving classification performance. International Journal of Remote Sensing , 28, 823-870

3. Manandhar, R. , Odeh, I. O. , \& Ancev, T. (2009). Improving the accuracy of land use and land cover classification of Landsat data using postclassification enhancement. Remote Sensing , 1, 330-344

4. Дейт К. Дж. Введение в системы баз данных . - 8-е изд. - М.: «Вильямс». - 2006. - ISBN 0-321-19784-4. - 1328 с.

5. Ситник В.Ф., Краснюк М.Т. Інтелектуальний аналіз даних (дейтамайнінг) К.: КНЕУ, 2007. - 367 с.

6. Gorokhovatskyi, V. and Polyakova, T. (2018), The use of spatial structures of signs for the classification of images in computer vision, FLP Panov A.N., Kharkov, 120 p.

7. Gorokhovatskyi, V. and Solodchenko, K. (2018), "The application system analysis and processing of the data bit in the methods of image classification for multiple key points", Control, navigation and communication systems, No. 2 (48), pp. 63-67. 
8. Хорошун Г. М., Метод опису явища дифракції по сукупності топологічних об'єктів та алгоритм розрізняння мінімуму від нуля інтенсивності, Харків, Сучасні Інформаційні Системи, прийнято до друку, вересень. -2020

9. Паклин Н.Б., Орешков В.И. Бизнес-аналитика: от данных к знаниям: Учеб. пособие. 2-е изд., перераб. и доп. - СПб.: Питер, 2010. - 704 с.

10. Khoroshun G., Luniakin R., Riazantsev A., Ryazantsev O., Skurydina T., Tatarchenko H. The Development of an Application for Microparticle Counting Using a Neural Network, Proceedings of the 4th International Conference on Computational Linguistics and Intelligent Systems (COLINS 2020). Volume I: Main Conference, p. 1186-1195

11. Khoroshun A.N. Optimal linear phase mask for the singular beam synthesis from a Gaussian beam and the scheme of its experimental realization, Journal of Modern Optics Vol. 57, No. 16, 20 September 2010, 1542-1549

12. Bekshaev A, Chernykh A, Khoroshun A, Masajada J, PopiołekMasajada A, Ryazantsev A. Controllable singular skeleton formation by means of the Kummer optical-vortex diffraction at a rectilinear phase step. Journal of Optics. 2020 Nov 27.

13. Khoroshun, A. N., Chernykh, A. V., Tatarchenko, H. O., Bekshaev, A. Y., \& Akhmerov, A. A. (, January). Laguerre-Gaussian beam transformations by the double-phase-ramp converter: Singular skeleton formation and its sensitivity to small misalignments. In Thirteenth International Conference on Correlation Optics, SPIE, 2018 (Vol. 10612, p. 1061203).

14. Полицинский Е.В. Физика. Понимание учебного материала через решение фризических задач. Учебное пособие: учебное пособие / Е.В. Полицинский. - ИПЛЮТИ ТПУ, 2004 - 114 с.

\section{References}

1. Kvyetnyy, R. N., and O. A. Reminnyy. "Vysokoshvydkisnyy metod klasyfikatsiyi zobrazhen [High-speed image classification method] (2009).

2. Lu, D. , \& Weng, Q. A. (2007). Survey of image classification methods and techniques for improving classification performance. International Journal of Remote Sensing , 28, 823-870

3. Manandhar, R. , Odeh, I. O. , \& Ancev, T. (2009). Improving the accuracy of land use and land cover classification of Landsat data using postclassification enhancement. Remote Sensing , 1, 330-344

4. Dejt K. Dzh. Vvedenie v sistemy baz dannyh [Introduction to Database Systems]. - 8-e izd. - M.: «Vil'yams». - 2006. - ISBN 0-321-19784-4. - $1328 \mathrm{~s}$.

(deytamayninh)

5. Sytnyk V.F., Krasnyuk M.T. Intelektual'nyy analiz danykh Data mining] K.: KNEU, 2007. - 367 c.

6. Gorokhovatskyi, V. and Polyakova, T. (2018), The use of spatial structures of signs for the classification of images in computer vision, FLP Panov A.N., Kharkov, 120 p.

7. Gorokhovatskyi, V. and Solodchenko, K. (2018), "The application system analysis and processing of the data bit in the methods of image classification for multiple key points", Control, navigation and communication systems, No. 2 (48), pp. 63-67.

8. Khoroshun H. M., Metod opysu yavyshcha dyfraktsiyi po sukupnosti topolohichnykh ob"yektiv ta alhorytm rozriznyannya minimumu vid nulya 
intensyvnosti [Method of description of the phenomenon of diffraction on by the set of topological objects and the algorithm for distinguishing the minimum from zero intensity], Kharkiv, Suchasni Informatsiyni Systemy, pryynyato do druku, veresen'. 2020

9. Paklyn N.B., Oreshkov V.Y. Byznes-analytyka: ot dannykh k znanyyam [Business analytics: from data to knowledge]: Ucheb. posobye. 2-e yzd., pererab. y dop. - SPb.: Pyter, 2010. - 704 s.

10. Khoroshun G., Luniakin R., Riazantsev A., Ryazantsev O., Skurydina T., Tatarchenko $\mathrm{H}$. The Development of an Application for Microparticle Counting Using a Neural Network, Proceedings of the 4th International Conference on Computational Linguistics and Intelligent Systems (COLINS 2020). Volume I: Main Conference, p. 1186-1195

11. Khoroshun A.N. Optimal linear phase mask for the singular beam synthesis from a Gaussian beam and the scheme of its experimental realization, Journal of Modern Optics Vol. 57, No. 16, 20 September 2010, 1542-1549

12. Bekshaev A, Chernykh A, Khoroshun A, Masajada J, PopiołekMasajada A, Ryazantsev A. Controllable singular skeleton formation by means of the Kummer optical-vortex diffraction at a rectilinear phase step. Journal of Optics. 2020 Nov 27.

13. Khoroshun, A. N., Chernykh, A. V., Tatarchenko, H. O., Bekshaev, A. Y., \& Akhmerov, A. A. (, January). Laguerre-Gaussian beam transformations by the double-phase-ramp converter: Singular skeleton formation and its sensitivity to small misalignments. In Thirteenth International Conference on Correlation Optics, SPIE, 2018 (Vol. 10612, p. 1061203).

14. Polytsynskyy E.V. Fyzyka. Ponymanye uchebnoho materyala cherez reshenye fyzycheskykh zadach [Understanding of educational material through solving physical problems] Uchebnoe posobye: uchebnoe posobye / E.V. Polytsynskyy. - YPLYuTY TPU, 2004-114 s.

Поступила в редакцию 10.12.2020, рассмотрена на редколлегии 10.12.2020

\section{CLASSIFICATION METHOD OF OPTICS AND LASER PHYSICS PROBLEMS}

In recent decades, due to the use of computer technology, the results of research in a particular area of science and technique are accumulated very quickly. In the process of creating a database of optical images and knowledge base is appeared the task of classification method absence. Without such a method the creating the structure of data warehouse is difficult to solve. The classification of the tasks and the obtained results requires considerable attention in order to ensure their rapid and accurate search and further use. Classification is one of the most important tasks of large database analysis used in Data Mining. Assessment of classification accuracy can be performed using cross-checking or a test set. The proposed method is suitable for use when the accuracy of the test set classification meets the established requirements. In the field of optics and laser physics dealt with the problem, which usually is grouped by the next attributes: the initial field pattern, the type of the optical system, the characteristics of the obtained spatial distribution of light as the number of maxima, minima, zeros of intensity and other significant objects. The question of classification of the tasks themselves was considered in the 
paper for the first time. The method of classification of problems in optics and laser physics is developed. It is applied to the problems of diffraction, interference and observation of microobjects. The classification is carried out with the help of mathematical methods, a formal description of the objects and the decision trees method. The 5 classes was chosen: "meaning the task", "solution method", "appointment", "complexity", "way of expression." The attributes of the problem classification are "visual-optical", "optical", "computational", "experimental", "qualitative", "fundamental", "applied", "simple", "complex", "textual", "numerical", "graphical". The scheme of problems in optics and laser physics classification is shown. Decision-making to determine the attributes of the problem is carried out using the decision trees method. Application of the results in search engines of big databases and pattern recognition problems is discussed.

Key words: classification of tasks; decision tree; optical image.

\section{Відомості про авторів}

Хорошун Ганна Миколаївна - кандидат фрізико-математичних наук, доцент, доцент кафедри будівництва, урбаністики та просторового планування, докторант по спеціальності 05.13.06 Інфрормаційні технології.

Східноукраїнський національний університет імені Володимира Даля, м. Сєвєродонецьк, Україна e-mail: an khor@i.ua;

ORCID ID: http://orcid.org/ 0000-0002-1272-1222.

\section{About the Authors}

Khoroshun Ganna - Dr. of Philosophy in Optics and Laser Physics, Associated Professor of Department of Construction, Urban and Spatial Planning, doctoral student on the speciality 05.13.06 - Information technologies.

Volodymyr Dahl East Ukrainian National University, Tsentralniy av. 59-A, Severodonetsk, Ukraine, 93404

E-mail: an khor@i.ua; ORCID ID: http://orcid.org/ 0000-0002-1272-1222 